\title{
An Entry of the Chemoselective Sulfo-Click reaction into the Sphere of Nucleic Acids
}

\author{
Guillaume Clavé*, Enes Dursun, Jean-Jacques Vasseur and Michael Smietana* \\ Institut des Biomolécules Max Mousseron, Univ. Montpellier, CNRS, ENSCM, Montpellier, France
}

Supporting Information Placeholder

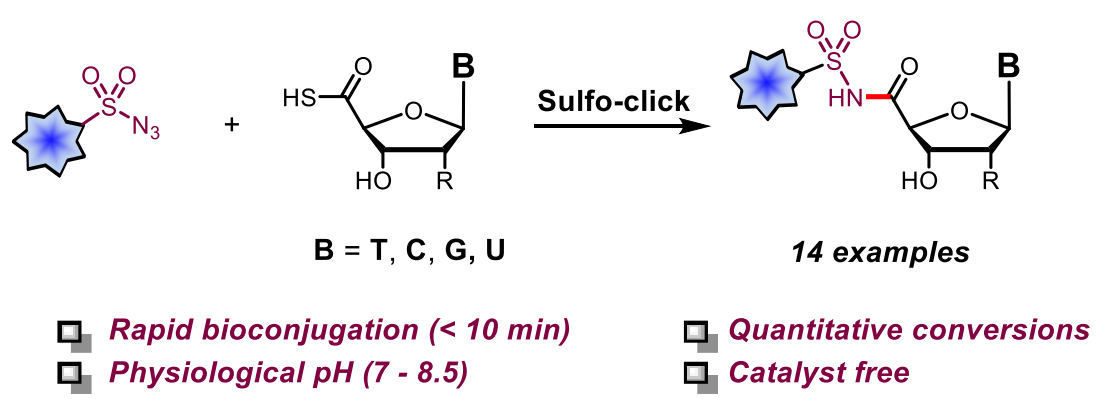

\begin{abstract}
We report here the first example of a sulfo-click conjugation reaction to be applied to modified nucleosides. The reaction, which proceeds rapidly $\left(k \sim 4.9 \times 10^{-3} \mathrm{M}^{-1} \mathrm{~s}^{-1}\right)$ under aqueous biocompatible conditions in both the ribo- and the deoxyribonucleoside series, affords the corresponding conjugated products in excellent yields. Furthermore, we demonstrate the orthogonality of the reaction with the copper-catalyzed azide-alkyne click reaction (CuAAC) by performing a one-pot dual labeling of a nucleoside carrying two orthogonal azido groups.
\end{abstract}

Site-specific bioconjugation and labeling of biomolecules to different partners (i.e. fluorophore, vectors, affinity tags, ...) has become an essential tool for understanding and imaging cellular processes. ${ }^{1}$ In particular, the unique advantages of biocompatible click reactions that combine bioorthogonality, efficiency and chemoselectivity have provided important advances for the development of new diagnostic and therapeutic applications. While many bioorthogonal ligations have been applied to proteins, ${ }^{2}$ lipids, ${ }^{3}$ saccharides, ${ }^{4}$ and DNA, ${ }^{5}$ the site-specific 5 ' modification of ribo- and deoxyribonucleosides is rather limited to classical coupling reactions ${ }^{6}$ or click derived methodologies ${ }^{7}$ that cannot support biocompatible conditions (Figure 1). The selective coupling of different labels to nucleosides is however important to increase their biological activity, drug resistance or their bioavailability but also for imaging purposes. $^{8}$

The reaction between azides and thioacids also known as thioacid-azide ligation (TAL) is an emergent surrogate click reaction that upon a stepwise addition-cycloaddition-retro [3+2] cycloaddition sequence leads to an amide linkage generating elemental sulfur and dinitrogen as the sole by-products. First described as a side reaction in 1980, ${ }^{9}$ it was only in 2003 that Williams and co-workers highlighted its potential as an original amidation reaction in a neutral or basic medium. ${ }^{10}$ While the use of aliphatic azides requires heating at $60{ }^{\circ} \mathrm{C}$ for several hours, it has been demonstrated that electron-deficient azides ${ }^{11}$ readily react at $\mathrm{rt}$. In 2010, in their study pertaining to the site-specific conjugation of peptides,
Figure 1. Known 5' nucleoside coupling reactions
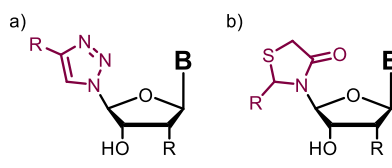

c)

d)
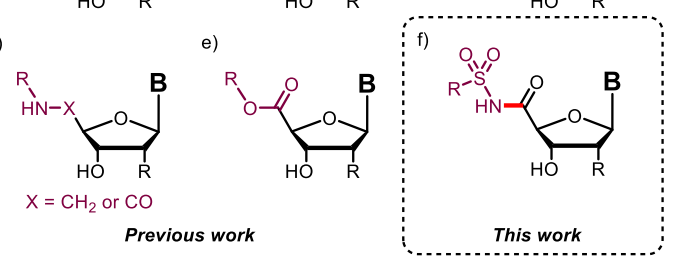

Liskamp et al. unveiled the 'sulfo-click' between a thioacid and a sulfonyl azide, ${ }^{12}$ which was later used in various applications, including protein and carbohydrate modification by several research groups. ${ }^{13}$ The reactions are generally complete within $10 \mathrm{~min}$ at room temperature either in organic or aqueous media in the presence of a base. Interestingly, the sulfo-click is one of the few click reactions that can generate a native amide linkage, ${ }^{14}$ and does not require obtrusive bulky or hydrophobic reactive moieties compared to other click reactions (e.g. tetrazine, norbornene, cyclooctyne...). Despite these interesting properties, the sulfo-click reaction has surprisingly never been applied to nucleic acid derivatives if we exclude the thioacid-azide 

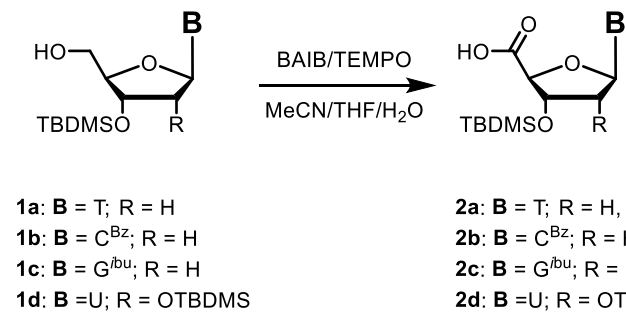

2a: $\mathbf{B}=\mathrm{T} ; \mathrm{R}=\mathrm{H}, 77 \%$

2b: $\mathbf{B}=\mathrm{C}^{\mathrm{Bz}} ; \mathrm{R}=\mathrm{H}, 71 \%$

2c: $\mathbf{B}=\mathrm{G}^{\text {ibu }} ; \mathrm{R}=\mathrm{H}, 86 \%$

2d: $\mathbf{B}=\mathrm{U} ; \mathrm{R}=$ OTBDMS, $94 \%$

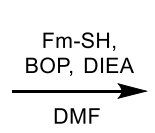

DMF

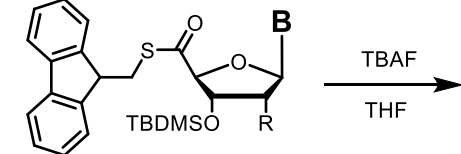

3a: $\mathbf{B}=\mathrm{T} ; \mathrm{R}=\mathrm{H}, 87 \%$

3b: $\mathbf{B}=\mathrm{C}^{\mathrm{Bz}} ; \mathrm{R}=\mathrm{H}, 73 \%$

3c: $\mathbf{B}=\mathrm{G}^{\text {ibu }} ; \mathrm{R}=\mathrm{H}, 85 \%$

3d: $\mathbf{B}=\mathrm{U} ; \mathrm{R}=$ OTBDMS, $94 \%$

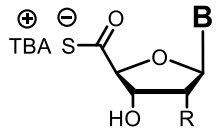

4a: $\mathbf{B}=\mathrm{T} ; \mathrm{R}=\mathrm{H}, 70 \%$

4b: $\mathbf{B}=\mathrm{C}^{\mathrm{Bz}} ; \mathrm{R}=\mathrm{H}, 59 \%$

4c: $\mathbf{B}=\mathrm{G}^{\text {ibu}} ; \mathrm{R}=\mathrm{H}, 93 \%$

4d: $\mathbf{B}=\mathrm{U} ; \mathrm{R}=\mathrm{OH}$, quant. ligation performed on a non-activated 3'-azido-3'-deoxythymidine with thioacetic and thiobenzoic acids at $60^{\circ} \mathrm{C}$ for $36 \mathrm{~h}$ reported by Shangguan and co-workers. ${ }^{10 a}$

Considering our interest in the development of 5'-modified nucleoside derivatives for the formation of new internucleoside linkages ${ }^{15}$ and the potential of the sulfo-click reaction to generate functional bioconjugates, we decided to explore its compatibility with nucleic acids by focusing on the introduction of the thioacid moiety at the 5 ' position. We describe herein our endeavor and demonstrate that 4'-thioacid-modified deoxyribo- and ribonucleosides can be readily conjugated to various small molecules in water at very low concentrations.

The synthesis of 4'-thioacid nucleosides was developed through an efficient three-step sequence from 3'-O-TBDMSnucleosides (Scheme 1). The 5'-hydroxyl nucleosides 1a-d were oxidized to the corresponding carboxylic acids $\mathbf{2 a - d}$ using TEMPO in the presence of BAIB as co-oxydant. ${ }^{16}$ A coupling reaction with 9-fluorenylmethylthiol (Fm) generated the corresponding thioesters 3a-d in high yields. Previous works have reported the in situ generation of thioacids in the context of the sulfo-click reaction from base-sensitive thioesters. ${ }^{13 b, 17}$ However, Fm thioesters have been shown to be stable in aqueous media at physiological $\mathrm{pH}$. Therefore, we decided to generate the unprotected 4'-thioacid nucleoside derivatives $\mathbf{4 a - d}$ by treatment with TBAF in THF leading to the desired compounds in the form of tetrabutylammonium (TBA) thiocarboxylate salts. To prevent possible hydrolysis of the thioacids under acidic ${ }^{18}$ or basic ${ }^{19}$ aqueous media, the thiocarboxylate nucleosides were purified as such by normal phase chromatography. Noteworthy, all thiocarboxylate nucleosides salts were completely stable at $-20^{\circ} \mathrm{C}$ for months but are likely to degrade at rt.

Then, a series of sulfonyl azide partners were synthesized in one step upon classical peptide coupling conditions by using the 2aminoethanesulfonyl azide as a short linker. ${ }^{20}$ Different classes of labels were selected to demonstrate the versatility of the sulfo-click reaction applied to nucleoside derivatives; these include biotin $\mathbf{6 a}$, an amino acid $\mathbf{6 b}$, a modified nucleoside $\mathbf{6 c}$, a fluorophore $\mathbf{6 d}$ and a peptide 6e (Scheme 2).

A preliminary kinetic study run with 4'-thiocarboxylate uridine $\mathbf{4 d}$ and sulfonyl azide thymidine $\mathbf{6 c}$ showed that the reaction reached complete conversion within $10 \mathrm{~min}$ at $\mathrm{rt}$ under aqueous conditions $\left(10 \mathrm{mM}\right.$ of sulfonyl azide in aq. 0.1 $\mathrm{M} \mathrm{NaHCO}_{3}$ buffer $\mathrm{pH}$ 8.5/NMP 25:75 mixture) (see ESI Figure S2). Under the aforementioned conditions, the sulfonyl azides previously synthesized (Scheme 2 ) were successfully conjugated to all thioacetate $\mathbf{4 a - d}$ leading to various 5'-labeled nucleo- sides in excellent yields including biotin, which is often coupled to biomolecules as a tool for biological applications, ${ }^{21}$ and the hydrosoluble fluorophore Cy 5.0, used for in vivo imaging (Scheme 3). ${ }^{22}$ Similarly, 5',5'-dinucleotides bearing a non-natural $N$-acyl sulfonamide linkage were also obtained in good to excellent yields. Remarkably, the sulfo-click reaction proceeded efficiently with sulfonyl azide $\mathbf{6} \mathbf{b}$ demonstrating the orthogonality of the reaction in the presence of a free primary amine. Ultimately, we were able to implement the sulfo-click on the hexapeptide Ac-GFVANE- $\mathrm{NH}_{2}$, which underlined the potential of the reaction on larger molecules. All reactions were monitored by RP-HPLC analysis, which confirmed the complete conversion of the sulfonyl azide within the ten first minutes. Following these results, we next evaluated the rate of the sulfo-click reaction at low concentrations by monitoring the formation of the $\mathrm{N}$-acyl sulfonamide $\mathbf{1 0}$ (Table 1).

\section{Scheme 2. Sulfonyl azide compounds synthesized}
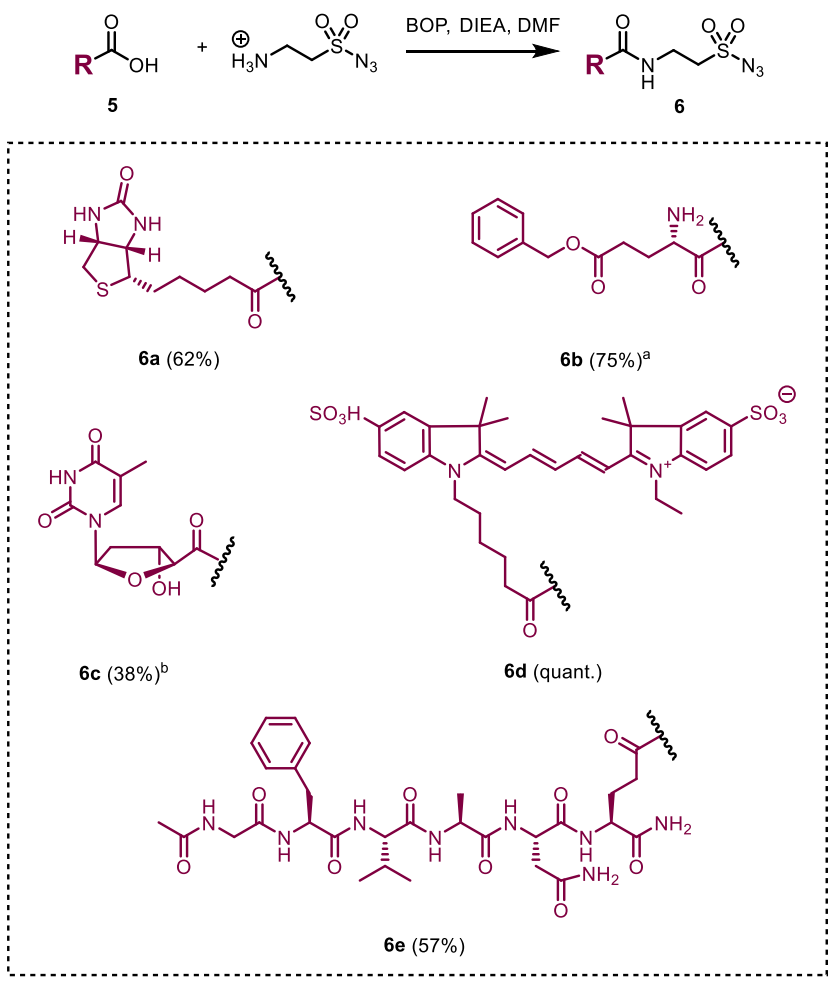

aield over two steps after $\mathrm{N}$-Boc deprotection. 'Yield over two steps after 3'-OTBDMS deprotection. 

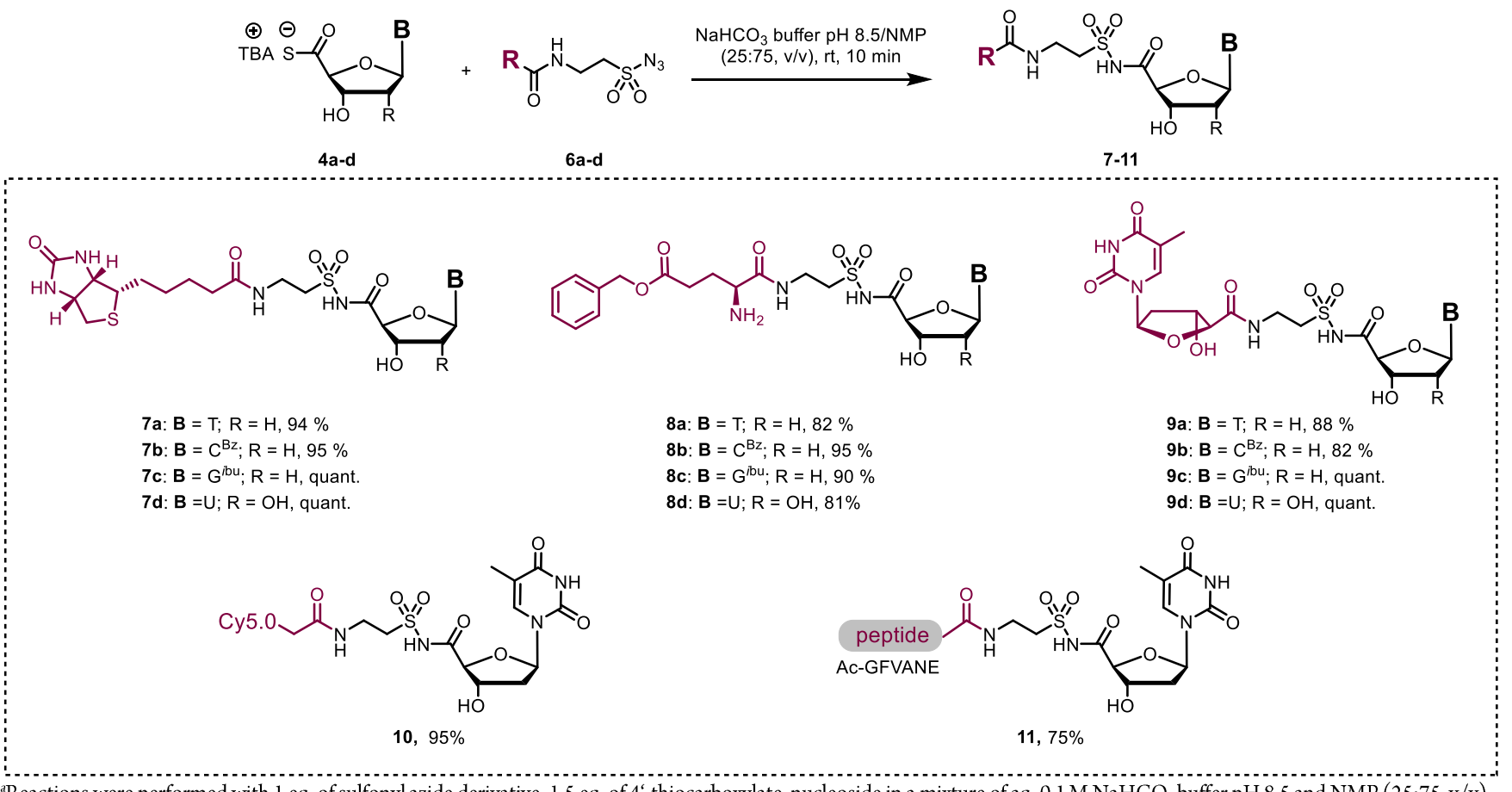

${ }^{a}$ Reactions were performed with 1 eq. of sulfonyl azide derivative, 1.5 eq. of 4 -thiocarboxylate nucleoside in a mixture of aq. $0.1 \mathrm{M} \mathrm{NaHCO}$ buffer $\mathrm{pH} 8.5$ and $\mathrm{NMP}(25: 75$, v/v).

The data demonstrated that the reaction still occurred rapidly even at $1 \mathrm{mM}$ concentration reaching completion within $5 \mathrm{~h}$. Interestingly, under more dilute conditions $(100$ and $10 \mu \mathrm{M})$, the ligation still occurred albeit at a slower rate. All-in-all, these results demonstrated the applicability of the sulfo-click reaction at low concentrations. The longer reaction timers were not detrimental as both the thioacid and the sulfonyl azide are stable in aqueous media under physiological conditions for dozens of hours. Kinetic analysis unveiled a second-order kinetic constant $\left(k=4.9 \times 10^{-3} \mathrm{M}^{-1} \mathrm{~s}^{-1}\right)$ at $37^{\circ} \mathrm{C}$, which is of the same order of magnitude than the one determined earlier in organic media $\left(k=5.7 \times 10^{-3} \mathrm{M}^{-1} \mathrm{~s}^{-1}\right)^{10 \mathrm{~b}}$ and comparable to those of the Staudinger ligation $\left(k \sim 10^{-4}-10^{-3} \mathrm{M}^{-1} \mathrm{~s}^{-1}\right)$ or the SPAAC $\left(k \sim 10^{-2}\right.$ $\left.10^{-1} \mathrm{M}^{-1} \mathrm{~s}^{-1}\right) .^{23}$

Encouraged by these results, we decided to evaluate the possibility to carry out a one-pot sulfo-click/CuAAC sequence on a substrate carrying two azido groups. Based on the high reactivity of the electron-deficient sulfonyl azide, we assumed a complete orthogonality of the two azido groups. We thus designed a modified nucleoside bearing both a sulfonyl azide and an aliphatic azide at the 5' and 3' positions respectively. Its synthesis started with commercially available azidothymidine which was first oxidized using the TEMPO/BAIB conditions described above, leading to carboxylic acid 12. A coupling reaction between 12 and 2aminoethanesulfonyl azide using BOP reagent in the presence of DIEA allowed the formation of the corresponding di-azidothymidine 13. The latter was then subjected to a one-pot doubleclick sulfo-click/CuAAC conjugation sequence (Scheme 4). First, the sulfo-click was performed at $37{ }^{\circ} \mathrm{C}$ with a slight excess of 4'-thiocarboxylate-thymidine $\mathbf{4 a}$ in a $\mathrm{NaHCO}_{3}$ buffer $(0.1 \mathrm{M}, \mathrm{pH}$ 8.5)/NMP mixture (1:4) resulting in a successful chemoselective and quantitative conjugation after $10 \mathrm{~min}$ (determined by RP-
HPLC, see Figure S1). CuI, DIEA and commercially available biotin alkyne $\mathbf{1 4}$ were then added leading to the quantitative formation of the desired bis-conjugate $\mathbf{1 5}$ after $30 \mathrm{~min}$ ( $86 \%$ isolated yield). This result demonstrated that both reactions could be run sequentially and highlighted the tunability of the azido groups for dual conjugation.

In summary, we report here the first application of the sulfo-click chemistry on nucleoside derivatives. A straightforward sequence was developed to access deoxyribo- and ribonucleosides bearing a 4'-thioacetate group, allowing the successful implementation of the sulfo-click conjugation to this particular class of biomolecules. Quantitative reactions were observed within $10 \mathrm{~min}$ at 10 $\mathrm{mM}$ concentration. The transformation is rapid $\left(k=4.9 \times 10^{-3} \mathrm{M}^{-1} \mathrm{~s}\right.$ $\left.{ }^{1}\right)$ under biocompatible conditions even at low micromolar concentrations. Moreover, we were able to implement the method to a one-pot sequential sulfo-click/CuAAC to selectively introduce two conjugations starting from a di-azido precursor.

Table 1. Kinetic studies of the sulfo-click reaction under physiological conditions ${ }^{a}$

\begin{tabular}{ccc} 
Concentration $(\mu \mathrm{M})$ & Half conversion $(\mathrm{h})$ & $\begin{array}{c}\text { Quantitative } \\
\text { conversion }(\mathrm{h})\end{array}$ \\
\hline 1000 & 0.6 & $\sim 5$ \\
100 & 2 & $\sim 20$ \\
10 & 7 & $\sim 40$
\end{tabular}

${ }^{a}$ Reactions were performed at $37^{\circ} \mathrm{C}$ with 1 eq. of Cy 5.0 sulfonyl azide derivative, 2 eq. of 4-thiocarboxylate uridine in a mixture of aq. $50 \mathrm{mM}$ TEAA buffer $\mathrm{pH} 7$ and $\operatorname{NMP}(50 \%$ at $1 \mathrm{mM}, 5 \%$ at $100 \mu \mathrm{M}$ and $0.5 \%$ at $10 \mu \mathrm{M})$ 
Scheme 4. Bioorthogonal of one-pot double click conjugation

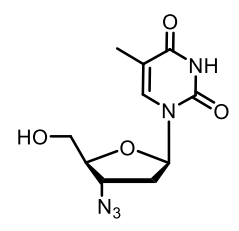

11

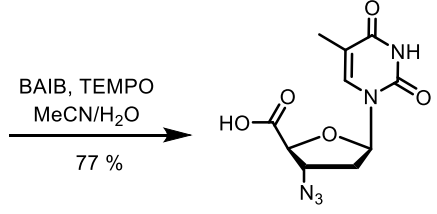

12

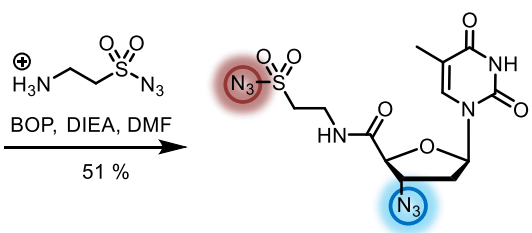

13

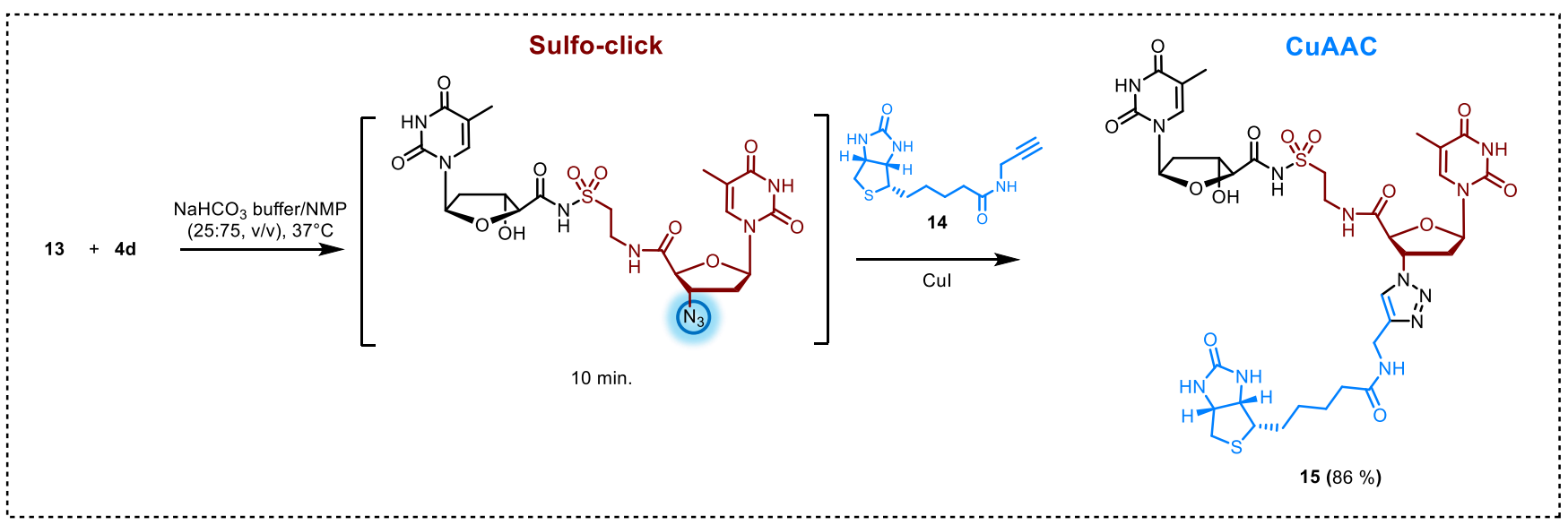

\section{ASSOCIATED CONTENT}

\section{Supporting Information}

The Supporting Information is available free of charge on the ACS Publications website.

Experimental synthetic procedures and characterizations with detailed descriptions of TAL kinetic studies (PDF)

\section{AUTHOR INFORMATION}

\section{Corresponding Authors}

*E-mail: guillaume.clave@cnrs.fr

*E-mail: michael.smietana@umontpellier.fr

\section{ORCID}

Guillaume Clavé: 0000-0001-6401-0935

Michael Smietana: 0000-0001-8132-7221

Jean-Jacques Vasseur: 0000-0002-4379-6139

\section{Notes}

The authors declare no competing financial interest.

\section{ACKNOWLEDGMENT}

The authors thank the Agence Nationale de la Recherche (ANR “TALAN"-ANR-19-CE07-0004-01) for financial support.

\section{REFERENCES}

1.(a) Sletten, E. M.; Bertozzi, C. R., Bioorthogonal chemistry: fishing for selectivity in a sea of functionality. Angew. Chem. Int. Ed. 2009, 48, 6974-6998; (b) Cañeque, T.; Müller, S.; Rodriguez, R., Visualizing biologically active small molecules in cells using click chemistry. Nat. Rev. Chem. 2018, 2, 202-215; (c)
Kenry; Liu, B., Bio-orthogonal Click Chemistry for In Vivo Bioimaging. Trends Chem. 2019, 1, 763-778; (d) Ivancova, I.; Leone, D. L.; Hocek, M., Reactive modifications of DNA nucleobases for labelling, bioconjugations, and crosslinking. Curr. Opin. Chem. Biol. 2019, 52, 136-144.

2.(a) Griffin, B. A.; Adams, S. R; Tsien, R. Y., Specific covalent labeling of recombinant protein molecules inside live cells. Science 1998, 281, 269-272; (b) Blackman, M. L.; Royzen, M.; Fox, J. M., Tetrazine ligation: fast bioconjugation based on inverse-electron-demand Diels-Alder reactivity. J. Am. Chem. Soc. 2008, 130, 13518-13519; (c) Karver, M. R; Weissleder, R.; Hilderbrand, S. A., Bioorthogonal reaction pairs enable simultaneous, selective, multi-target imaging. Angew. Chem. Int. Ed. 2012, 51, 920-922; (d) Wang, Q.; Chan, T. R.; Hilgraf, R.; Fokin, V. V.; Sharpless, K. B.; Finn, M., Bioconjugation by copper (I)-catalyzed azide-alkyne [3+ 2] cycloaddition. J. Am. Chem. Soc. 2003, 125, 3192-3193.

3.(a) Neef, A. B.; Schultz, C., Selective fluorescence labeling of lipids in living cells. Angew. Chem. Int. Ed. 2009, 48, 1498-1500; (b) Kho, Y.; Kim, S. C.; Jiang, C.; Barma, D.; Kwon, S. W.; Cheng, J.; Jaunbergs, J.; Weinbaum, C.; Tamanoi, F.; Falck, J., A tagging-via-substrate technology for detection and proteomics of farnesylated proteins. Proc. Natl. Acad. Sci. U.S.A. 2004, 101, 12479-12484.

4.(a) Kayser, H.; Zeitler, R.; Kannicht, C.; Grunow, D.; Nuck, R.; Reutter, W., Biosynthesis of a nonphysiological sialic acid in different rat organs, using $\mathrm{N}$ propanoyl-D-hexosamines as precursors. J. Biol. Chem. 1992, 267, 1693416938; (b) Mahal, L. K.; Yarema, K. J.; Bertozzi, C. R., Engineering chemical reactivity on cell surfaces through oligosaccharide biosynthesis. Science 1997, 276, 1125-1128; (c) Agard, N. J.; Prescher, J. A.; Bertozzi, C. R., A strainpromoted [3+2] azide- alkyne cycloaddition for covalent modification of biomolecules in living systems. J. Am. Chem. Soc. 2004, 126, 15046-15047; (d) Andersen, K. A.; Aronoff, M. R; McGrath, N. A.; Raines, R. T., Diazo groups endure metabolism and enable chemoselectivity in cellulo. J. Am. Chem. Soc 2015, 137, 2412-2415; (e) Niederwieser, A.; Späte, A. K.; Nguyen, L. D.; Jüngst, C.; Reutter, W.; Wittmann, V., Two-color glycan labeling of live cells by a combination of Diels-Alder and click chemistry. Angew. Chem. Int. Ed. 2013, $52,4265-4268$

5.(a) Seo, T. S.; Li, Z.; Ruparel, H.; Ju, J., Click chemistry to construct fluorescent oligonucleotides for DNA sequencing. J. Org. Chem. 2003, 68, 609612; (b) Salic, A.; Mitchison, T. J., A chemical method for fast and sensitive 
detection of DNA synthesis in vivo. Proc. Nati. Acad. Sci. USA 2008, 105 2415-2420; (c) Gierlich, J.; Burley, G. A.; Gramlich, P. M.; Hammond, D. M.; Carell, T., Click chemistry as a reliable method for the high-density postsynthetic functionalization of alkyne-modified DNA. Org. Lett. 2006, 8 3639-3642; (d) Werther, P.; Möhler, J. S.; Wombacher, R., A Bifunctional Fluorogenic Rhodamine Probe for Proximity-Induced Bioorthogonal Chemistry. Chem. Eur.J. $\quad 2017,23,18216-18224$; (e) Schoch, J.; Wiessler, M.; Jäschke, A., Post-Synthetic Modification of DNA by InverseElectron-Demand Diels-Alder Reaction. J. Am. Chem. Soc. 2010, 132, 88468847; (f) Winz, M.-L.; Linder, E. C.; Becker, J.; Jäschke, A., Site-specific one-pot triple click labeling for DNA and RNA. Chem. Commun. 2018, 54, 1178111784.

6.(a) Varizhuk, A.; Kochetkova, S.; Kolganova, N.; Timofeev, E.; Florentiev, V., Oligonucleotide analogs with peptide internucleotide linkages. Nucleosides Nucleotides Nucleic Acids 2011, 30, 31-48; (b) Doherty, W.; Dürr, E.-M.; Baddock, H. T.; Lee, S. Y.; McHugh, P. J.; Brown, T.; Senge, M. O.; Scanlan, E. M.; McGouran, J. F., A hydroxamic-acid-containing nucleoside inhibits DNA repair nuclease SNM1A. Org. Biomol. Chem. 2019, 17, 8094-8105.

7.(a) Calcerrada-Munoz, N.; O'Neil, I.; Cosstick, R, Novel macrocycles derived from nucleosides. Nucleosides Nucleotides Nucleic Acids 2001, 20, 1347-1350; (b) Shen, F.; Li, X.; Zhang, X.; Yin, Q.; Qin, Z.; Chen, H.; Zhang, J.; Ma, Z., Microwave-assisted synthesis of dinucleoside analogues containing a thiazolidin-4-one linkage via one-pot tandem Staudinger/azaWittig/cyclization. Org. Biomol. Chem. 2011, 9, 5766-5772; (c) Peterson, T. V.; Streamland, T. U.; Awad, A. M., A tractable and efficient one-pot synthesis of 5'-Azido-5'-deoxyribonucleosides. Molecules 2014, 19, 2434-2444; (d) Baraniak, D.; Ruszkowski, P.; Baranowski, D.; Framski, G.; Boryski, J., Nucleoside dimers analogs containing floxuridine and thymidine with unnatural linker groups: synthesis and cancer line studies. Part III. Nucleosides Nucleotides Nucleic Acids 2019, 38, 980-1005; (e) Rana, N.; Huang, S.; Patel, P.; Samuni, U.; Sabatino, D., Synthesis, characterization and anti-cancer activity of a peptide nucleolipid bioconjugate. Bioorg. Med. Chem. Lett. 2016, 26, 3567-3571; (f) Bege, M.; Bereczki, I.; Herczeg, M.; Kicsak, M.; Eszenyi, D.; Herczegh, P.; Borbas, A., A low-temperature, photoinduced thiol-ene click reaction: a mild and efficient method for the synthesis of sugar-modified nucleosides. Org. Biomol. Chem. 2017, 15, 9226-9233.

8.(a) Juliano, R. L.; Ming, X.; Nakagawa, O., The Chemistry and Biology of Oligonucleotide Conjugates. Acc. Chem. Res. 2012, 45, 1067-1076; (b) Ming, X.; Laing, B., Bioconjugates for targeted delivery of therapeutic oligonucleotides. Adv. Drug Deliv. Rev. 2015, 87, 81-89; (c) Benizri, S.; Gissot, A.; Martin, A.; Vialet, B.; Grinstaff, M. W.; Barthélémy, P., Bioconjugated Oligonucleotides: Recent Developments and Therapeutic Applications. Bioconjug. Chem. 2019.

9. Hakimelahi, G. H.; Just, G., A simple synthesis of 2, 2-disubstituted tetrahydrothiophenes. Tetrahedron Lett. 1980, 21, 2119-2122.

10.(a) Shangguan, N.; Katukojvala, S.; Greenberg, R.; Williams, L. J., The Reaction of Thio Acids with Azides: A New Mechanism and New Synthetic Applications. J. Am. Chem. Soc. 2003, 125, 7754-7755; (b) Kolakowski, R. V.; Shangguan, N.; Sauers, R. R; Williams, L. J., Mechanism of Thio Acid/Azide Amidation. J. Am. Chem. Soc. 2006, 128, 5695-5702.

11.(a) Mhidia, R.; Beziere, N.; Blanpain, A.; Pommery, N.; Melnyk, O., Assembly/disassembly of drug conjugates using imide ligation. Org. Lett. 2010, 12, 3982-3985; (b) Xie, S.; Fukumoto, R.; Ramström, O.; Yan, M., Anilide Formation from Thioacids and Perfluoroaryl Azides. J. Org. Chem. 2015, 80, 4392-4397.

12. Rijkers, D. T. S.; Merkx, R.; Yim, C.-B.; Brouwer, A. J.; Liskamp, R. M. J., 'Sulfo-click' for ligation as well as for site-specific conjugation with peptides, fluorophores, and metal chelators. J. Pept. Sci. 2010, 16, 1-5.

13.(a) Rohmer, K.; Mannuthodikayil, J.; Wittmann, V., Application of the Thioacid-Azide Ligation (TAL) for the Preparation of Glycosylated and Fluorescently Labeled Amino Acids. Isr. J. Chem. 2015, 55, 437-446; (b) Raz, R; Rademann, J., Fmoc-Based Synthesis of Peptide Thioacids for Azide Ligations via 2-Cyanoethyl Thioesters. Org. Lett. 2012, 14, 5038-5041; (c) Yim, C.-B.; Dijkgraaf, I.; Merkx, R.; Versluis, C.; Eek, A.; Mulder, G. E.; Rijkers, D. T. S.; Boerman, O. C.; Liskamp, R. M. J., Synthesis of DOTA-Conjugated Multimeric [Tyr3] Octreotide Peptides via a Combination of $\mathrm{Cu}(\mathrm{I})$-Catalyzed "Click" Cycloaddition and Thio Acid/Sulfonyl Azide "Sulfo-Click" Amidation and Their in Vivo Evaluation. J. Med. Chem. 2010, 53, 3944-3953; (d) Zhang, X.; Li, F.; Lu, X.-W.; Liu, C.-F., Protein C-Terminal Modification through Thioacid/Azide Amidation. Bioconjugate Chem. 2009, 20, 197-200; (e)
Urkow, J.; Bergman, C.; Wuest, F., Sulfo-click chemistry with 18F-labeled thio acids. Chem. Commun. 2019, 55, 1310-1313.

14. Shoji, T.; Fukutomi, H.; Okada, Y.; Chiba, K., Artificial bioconjugates with naturally occurring linkages: the use of phosphodiester. Beilstein J. Org. Chem. 2018, 14, 1946-1955.

15.(a) Luvino, D.; Baraguey, C.; Smietana, M.; Vasseur, J. J., Borononucleotides: synthesis, and formation of a new reversible boronate internucleosidic linkage. Chem. Commun. 2008, 2352-2354; (b) Martin, A. R; Barvik, I.; Luvino, D.; Smietana, M.; Vasseur, J.-J., Dynamic and Programmable DNA-Templated Boronic Ester Formation. Angew. Chem. Int. Ed. 2011, 50, 4193-4196; (c) Gimenez Molina, A.; Barvik, I.; Muller, S.; Vasseur, J. J.; Smietana, M., RNA-based boronate internucleosidic linkages: an entry into reversible templated ligation and loop formation. Org. Biomol. Chem. 2018, 16, 8824-8830; (d) Martin, A. R.; Mohanan, K.; Luvino, D.; Floquet, N.; Baraguey, C.; Smietana, M.; Vasseur, J.-J., Expanding the borononucleotide family: synthesis of borono-analogues of dCMP, dGMP and dAMP. Org. Biomol. Chem. 2009, 7, 4369-4377.

16. Epp, J. B.; Widlanski, T. S., Facile preparation of nucleoside-5 '-carboxylic acids. J. Org. Chem. 1999, 64, 293-295.

17. Namelikonda, N. K.; Manetsch, R., Sulfo-click reaction via in situ generated thioacids and its application in kinetic target-guided synthesis. Chem. Commun. 2012, 48, 1526-1528.

18. Cox, R. A.; Yates, K., Mechanistic studies in strong acids. VIII. Hydrolysis mechanisms for some thiobenzoic acids and esters in aqueous sulfuric acid, determined using the excess acidity method. Can. J. Chem. 1982, 60, 30613070 .

19. Cefola, M.; Peter, S. S.; Gentile, P. S.; Celiano, R. A. V., Rate of hydrolysis of thiolacetic acid in basic solutions. Talanta 1962, 9, 537-540.

20. Brouwer, A. J.; Merkx, R; Dabrowska, K.; Rijkers, D. T.; Liskamp, R. M., Synthesis and applications of $\beta$-aminoethanesulfonyl azides. Synthesis 2006, 2006, 455-460.

21.(a) Dundas, C. M.; Demonte, D.; Park, S., Streptavidin-biotin technology: improvements and innovations in chemical and biological applications. Appl. Microbiol. Biotechnol. 2013, 97, 9343-9353; (b) Ren, W. X.; Han, J.; Uhm, S.; Jang, Y. J.; Kang, C.; Kim, J.-H.; Kim, J. S., Recent development of biotin conjugation in biological imaging, sensing, and target delivery. Chem. Commun. 2015, 51, 10403-10418.

22. Ballou, B.; Ernst, L. A.; Waggoner, A. S., Fluorescence imaging of tumors in vivo. Curr. Med. Chem. 2005, 12, 795-805.

23. Lang, K.; Chin, J. W., Bioorthogonal reactions for labeling proteins. ACS Chem. Biol. 2014, 9, 16-20. 